\title{
There Goes My Image: The Perception of Male Librarians by Colleague, Student, and Self
}

\section{Locke J. Morrisey and Donald O. Case}

A study of 132 undergraduate students, 70 M.L.S. students, and 29 university librarians used twenty semantic differential word-pair scales to compare perceptions of male librarians among these groups. The investigation supports previous studies showing that librarians believe they are viewed in a more negative light than is the case. Male librarians and library students believed the public's image of themselves to be more submissive, meek, nervous, effeminate, reserved, following, subdued and less approachable, athletic, and attractive than the undergraduate sample actually saw them. Women and men respondents saw the male librarian differently, as measured by the frequency with which they used certain descriptors. In general, the members of the male library group felt the male librarian is looked upon negatively when he actually was looked upon quite positively by the other respondents.

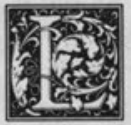

ibrarians have been concerned with what they perceive to be a poor public image for quite some time. ${ }^{1,2}$ Not long ago, American Libraries added a column on the public image of the librarian and asked readers to submit examples of librarian stereotypes. The results of this informal survey indicate that librarians believe that the first thing that comes to the public's mind is an image of a stereotypical spinster who spends her time quieting patrons whose voices rise above a whisper.

This negative image is reinforced by the media, especially in advertising. Nabisco, Frito-Lay, Dr. Pepper, Toyota and Ex-lax are all companies that have been accused of portraying librarians in stereotypical or other inaccurate ways. ${ }^{3,4.5}$ In one advertisement for an American Motors automobile, the vehicle was portrayed as so exciting that it frightened librarians. This advertisement drew enough protests to compel the company to publish an apology ${ }^{6}$

The comic strips For Better or for Worse and Bloom County; the television shows "Kate and Allie," "Murder She Wrote," and "Nova"; and Morgan Fairchild's beauty book, Super Look, have all portrayed librarians in a less than desirable light. ${ }^{7}$ Arnold Sable notes that the librarian may be viewed by the public as: "someone you would not want your son to marry, an ultimately pitiable figure with no 'outside interests'.... There at the

Locke J. Morrisey is Librarian at Hughes Aircraft Company, Electro-Optical and Data Systems Group, El Segundo, California 90245-0902, and Donald O. Case is Assistant Professor in the Graduate School of Library and Information Science at the University of California, Los Angeles, California 90024-1520. 
desk she will stay, stamping out her books, until her retirement.,"

Negative stereotypes of librarians hinder recruitment into the profession; diminish the respect librarians receive from client groups and administrators; inhibit individual and group initiative; and, ultimately, hinder the advancement of the profession.

Men in librarianship are doubly stigmatized. They are stereotyped because they work in a female-dominated profession and reflect the traditional negative image of librarians. A male librarian may be seen as an ineffectual, "kindly and sometimes effeminate misfit." nates directly from the conception of "librarianship-as-women's-work." 10 The resulting perception is that "no healthy man of normal intelligence should go into it . . . and no good man should be found dead in the library business."11

Male librarians are not alone in their need to deal with this problem. Men in other female-dominated professionsnursing ( 97 percent female) or elementary school teaching (84 percent female), for example-may also be perceived as effeminate. ${ }^{12,13}$ Some studies show that male librarians have a higher number of feminine traits in their personalities than males in general. ${ }^{14,15,16}$ This is not a perception that male librarians would wish to foster, and, in some cases, it may inhibit their professional functioning. Sable claims that "The male librarian wants first, before proving himself as a librarian, to prove himself as a male. He does not want to be considered as belonging to the female stereotype."17

Evidence in favor of this viewpoint is offered in J. Hart Walters' 1970 study in which the author demonstrates that men tend to be evasive about telling others they are librarians. ${ }^{18}$ Instead, male librarians opt for a more gender-neutral or masculine professional title, such as educator or information scientist. Further evidence of male concern about image is provided in Pauline Wilson's discovery that a disproportionately high percentage of the seventy-seven reviewed articles that treated the image of librarians were authored by male librarians. ${ }^{19}$
Researchers find that the feminine stereotype of the librarians is strongly pronounced among students of all ages. For children who lack contact with male members of the profession, portrayals on television, in films and in print play a powerful role in shaping their perceptions. As Martha Merrill says, "In the mass media, children do not see male librarians. ${ }^{\prime 20}$

\section{"Panek and others found librarians to be the third most strongly sex ster- eotyped occupation among the twenty-five job titles they exam- ined.'}

Even among adults, librarianship is still viewed as a feminine profession. In a 1977 study of 162 college students, Panek and others found librarians to be the third most strongly sex-stereotyped occupation among the twenty-five job titles they examined. ${ }^{21}$ Even more dramatically, Eva Shinar found that head librarian was the ninth "most feminine" among 129 occupations ranked by 120 college students; manicurist, receptionist, and prima ballerina ranked higher. ${ }^{22}$ Thus, a male librarian may be unrealistically viewed by the general public.

Student images of librarians tend to be negative, especially during high school. ${ }^{23,24}$ Librarians are perceived as proctors who remind students to be quiet or ban them from the library for minor infractions of the rules. Some of the adjectives students use to describe librarians are impersonal, cold, reserved, quiet, serious, and strict-perhaps not the worst impressions possible, but far from the best. ${ }^{25}$

Still, as more men and women enter cross-gender professions, these attitudes and stereotypes may be changing. Today, many librarians doubt that strong stereotypes continue to exist, except perhaps in the minds of colleagues preoccupied with this problem. Does a stereotype of male librarians exist? More specifically, does it exist on university campuses? If it does, what is it? Is it the same for both academic librarians and their patrons? 
The investigation reported here was conducted to determine the image of male librarians among librarians; future librarians (M.L.S. students); and clients (freshman English students). The survey, which was conducted at a large public university in fall 1985, compares male librarians' and male M.L.S. students' perceived images of male librarians to the actual image reported by the client population studied.

\section{METHODOLOGY}

A questionnaire was administered to classes and individuals at a university with a graduate library school and a large library system. It included semantic differential scales constructed of opposite or near opposite word pairs separated by a scale of 1 to $5 .^{26}$ These descriptors were chosen from standard sources, including the California Psychological Inventory and Harrison Gough's Adjective Check List, with four additions. ${ }^{27.28}$ Agada reviews the use of such techniques in studying the personality of librarians. ${ }^{29}$

Respondents were asked to circle the number that corresponded to their perception of the male librarian. A 1 represents a strong relation to the word printed on the left; a 5, a strong relation to the word on the right; and a 3, the neutral point. After rating the twenty word pairs, respondents were asked to indicate which three descriptors among all of the word pairs they would use to describe best the male librarian and to supply any other descriptors they thought appropriate.

Other questions asked freshman English and M.L.S. students about the number of times they used the library each quarter; their age, sex and class (freshman, sophomore, etc.); and the number of male librarians they knew. Librarians answered background questions regarding the number of their public service contact hours per week; age; sex; and number of years in the profession. Both forms encouraged comments on any of these items. In addition to the questionnaire, male M.L.S. students and male librarians were given another version of the twenty word pairs and were asked to record how they believed male librarians were perceived by others.
The distribution of the questionnaires was different for each group. Instructors of freshman English were sent a letter prior to the start of the fall quarter requesting them to distribute the questionnaires to students in their classes. Of the forty freshman English instructors contacted, fifteen responded to the initial letter and thirteen agreed to participate. The participating instructors were sent packets of questionnaires with a letter of appreciation and a brief explanation to be read to their class prior to the distribution of the survey instrument. The students were asked to complete the questionnaire outside of the classroom and to return it to the instructor at the next class period. A preaddressed envelope was provided. A total of fourteen class sections (one instructor taught two sections), averaging twentyfive students each, were surveyed. Of the 350 questionnaires distributed, 132 were returned for a 37.7 percent return rate. We do not know whether the opinions of the students who did not return, or were not given, the questionnaire differ in any way from those surveyed.

Because a policy against giving out mailing lists of campus librarians was in effect, the investigators asked twenty library directors to approve administration of the survey to librarians in their units; seven agreed. These librarians were given a questionnaire, a letter of instruction and a preaddressed return envelope. In all, forty-nine librarians were given questionnaires; twenty-nine questionnaires were returned for a return rate of 60 percent. This sample represents approximately 19 percent of the librarians in the campus library system.

All participants in the survey were asked to return their completed questionnaires by a date that fell within three weeks of their distribution. By then, 231 of 564 questionnaires had been returned for an overall response rate of 41 percent.

\section{RESULTS}

Descriptive (univariate and bivariate) results are presented below for each of the three groups surveyed: undergraduates, M.L.S. students, and working librarians. Responses across these groups are pre- 
sented and their implications discussed.

\section{Freshman English Students}

There were no statistically significant differences in the responses of students who indicated that they knew at least one male librarian (sixty-three students) and those who knew none (sixty-nine students). Thus, the image we expected to find held by the latter group was, in fact, no different than the image of the group that had actual experience with male librarians. This suggests that experience with male librarians had little or no effect on the respondents' perceived image of them.

Respondents chose descriptors among the twenty word pairs that they believed best described male librarians. The five descriptors most frequently chosen by freshman English students are listed in table 1 .

When these descriptors are examined separately by sex of respondent, they fall into a slightly different order. Both men and women undergraduates agree that organized is the single best descriptor ( 39 percent of the male respondents and 37 percent of the females listed it in first place). Both sexes placed approachable, logical, and patient among their top five descriptors. But, for 34 percent of the female respondents, friendly was the second-place response, although it did not appear in the male undergraduate short list.

Likewise, composed was in third place on the male list $(20$ percent of the male respondents picked that term) but did not make the top six terms picked by women undergraduate students. Approachable was chosen by 31 percent of female respondents but by only 18 percent of males. Male undergraduates see male librarians as organized and logical first, with other relatively neutral descriptors trailing far behind. On the whole, male librarians seem to evoke more emotionally positive responses from female than from male clients.

Respondents were also asked to choose their own words to describe male librarians. Sixty-one different responses were given, identifying thirty-one unique descriptors, six of which accounted for 59 percent of all responses. These descriptors, not listed among the twenty original word pairs, included helpful (eleven responses); intelligent (seven); knowledgeable (six); quiet (six); happy (three); and short (three). The last of these is presumed facetious.

We judged each original descriptor supplied by the respondent as either positive, negative, or neutral. If the word was thought to connote a good image of the male librarian, it was rated as positive. Examples are helpful, intelligent, and kind. If the word was thought to connote a poor image, it was rated negative. Examples are wimpy, badly dressed, and chauvinistic. If the word was thought to connote neither a good nor a poor image, it was rated neutral. Examples are quiet, cautious, and too smart. Judged thusly, thirty-one descriptors were declared positive, twenty-one negative, and ten neutral. When separated by sex of respondent, the descriptors chosen by women were found to be overwhelmingly positive (twenty-one positive, four negative, four neutral). The descriptors chosen by men were somewhat negative (ten positive, sixteen negative, six neutral). This suggests that men are more likely than women to view male librarians in a negative light.

\section{M.L.S. Students}

The five descriptors of male librarians most popular among M.L.S. students are listed in table 2.

When these results are partitioned by respondents' sex (there were fifty-one female and nineteen male respondents, approximating their proportions among the library school student body), the descriptor rankings are altered slightly. As was the case with the freshman English students, both the men and women in the group listed organized first ( 33 percent of women and 32 percent of men chose this descriptor). Women chose friendly almost as frequently as organized (31 percent), while men chose logical just as frequently (32 percent). This also follows the pattern seen among the freshman English students.

A departure occurs, however, with the addition of the negative words unathletic 
TABLE 1

TOP SIX WORDS CHOSEN BY UNDERGRADUATE

STUDENTS TO DESCRIBE MALE LIBRARIANS $(n=132)$

\begin{tabular}{llcc}
\hline Rank & Descriptor & $\begin{array}{c}\text { No. of } \\
\text { Responses }\end{array}$ & \% Respondents Choosing \\
\hline 1 & Organized & 50 & 37.9 \\
2 & Approachable & 33 & 25.0 \\
3 & Logical & 33 & 25.0 \\
4 & Friendly & 32 & 24.2 \\
5 & Patient & 26 & 19.7 \\
5 & Serious & 26 & 19.7 \\
\hline
\end{tabular}

TABLE 2

TOP FIVE WORDS CHOSEN BY M.L.S. STUDENTS TO DESCRIBE MALE LIBRARIANS $(n=70)$

\begin{tabular}{llcc}
\hline Rank & Descriptor & $\begin{array}{c}\text { No. of } \\
\text { Responses }\end{array}$ & \% Respondents Choosing \\
\hline 1 & Organized & 23 & 32.9 \\
2 & Friendly & 17 & 24.3 \\
3 & Logical & 16 & 22.9 \\
4 & Unathletic & 11 & 15.7 \\
4 & Serious & 11 & 15.7 \\
\hline
\end{tabular}

(18 percent of women M.L.S. students chose this term); conservative (chosen by 16 percent of female respondents); and effeminate (chosen by 16 percent of male respondents). This is perhaps due to M.L.S.student respondents judging male librarians on a more personal basis than freshman English students, whose only exposure to them may be in a library setting. Whatever the reason, the more negative descriptors came from librarians and prospective librarians.

When looking at respondent-supplied descriptors overall and using the same standard, twenty-three were positive, eight were negative and twelve neutral. When controlling for sex of the respondent, women's responses were positive overall (fourteen positive, seven negative, seven neutral) but slightly less so than those of the freshman English women, while men's responses were overwhelmingly positive (nine positive, one negative, five neutral) compared to the overall negative response of freshman English men. This indicates that M.L.S. students of both sexes see the male librarian in a very positive light. Yet female M.L.S. students judge the male librarian less positively than their freshman English coun- terparts, presumably because they know male librarians on a more personal basis and are more likely to find faults.

\section{Librarians}

Table 3 lists the male librarians top five descriptors among the twenty word pairs.

Again controlling for sex of respondent (twenty-two women, seven men), the responses are similar to those of both the freshman English and M.L.S. students. Among the women in the group, friendly, approachable, outspoken, and liberal were equally popular, while men chose organized, logical, leader, and unathletic. The emergence of the words outspoken, liberal, and leader suggests that the librarians are choosing words associated with professional image and status.

When asked to list other descriptors not included among the twenty word pairs, university librarian respondents supplied the following responses: intelligent (one male, three female respondents); selfish (four females); competent (three females); defensive (two females); gay (one male, one female).

Judging these additional descriptors by the same standards as before, nine are positive, eight negative and two neutral. 
TABLE 3

TOP FIVE WORDS CHOSEN BY UNIVERSITY

LIBRARIANS TO DESCRIBE MALE LIBRARIANS $(n=29)$

\begin{tabular}{llcc}
\hline Rank & Descriptor & $\begin{array}{c}\text { No. of } \\
\text { Responses }\end{array}$ & \% Respondents Choosing \\
\hline 1 & Organized & 6 & 20.7 \\
1 & Logical & 6 & 20.7 \\
1 & Leader & 6 & 20.7 \\
4 & Friendly & 5 & 17.2 \\
4 & Liberal & 5 & 17.2 \\
\hline
\end{tabular}

TABLE 4

TOP FIVE WORDS CHOSEN BY M.L.S. STUDENTS AND

UNIVERSITY LIBRARIANS TO DESCRIBE MALE LIBRARIANS $(n=99)$

\begin{tabular}{llcc}
\hline Rank & Descriptor & $\begin{array}{c}\text { No. of } \\
\text { Responses }\end{array}$ & \% Respondents Choosing \\
\hline 1 & Organized & 29 & 29.3 \\
2 & Friendly & 22 & 22.2 \\
2 & Logical & 22 & 22.2 \\
4 & Unathletic & 14 & 14.1 \\
5 & Serious & 13 & 13.1 \\
\hline
\end{tabular}

When partitioned by sex of respondent, women's responses were mixed (eight positive, eight negative, two neutral), while men's were very positive (two positive, one neutral). This suggests that female librarians are more critical of their male counterparts than the women in either of the other two groups. Again, this may be due to the fact that they have more personal contact with them than either of the other groups and thus are more likely to notice faults.

Table 4 is a combination of two preceding tables. It brings together the responses of both M.L.S. students and librarians. These responses were combined to form a librarians' group for comparison with the client group of freshman English students.

Comparisons of table 1 and table 4 contrast the ways in which library professionals (M.L.S. students and librarians) and

\footnotetext{
"The male librarian is seen no differently by those in the library group than he is by those outside the group, i.e., the general undergraduate public."
}

the client population view the male librarian. Overall, the results are strikingly similar, with organized, logical, and friendly among the top four responses of both the library professionals (see table 4) and the undergraduate students (see table 1 ). This suggests that the male librarian is seen no differently by those in the library group than he is by those outside the group, i.e., the general undergraduate public.

Table 5 summarizes and compares the polarity, i.e., positive-negative valence, of the descriptors chosen by each segment of the sample. One thing made clear by this table is the dissimilarity of M.L.S. students to the other two groups in terms of the polarity of responses: fully 28 percent of the library school student responses are neutral, compared to only 14 percent of the librarian and 16 percent of the undergraduate descriptors. It can be seen that this added neutrality originated in reduced choices of negative descriptors: only 19 percent of the M.L.S. student choices are negative, compared to 33 percent of the undergraduate and 38 percent of the librarian choices.

The investigators see two possible explanations for this: one is the tendency for young professionals in an advanced degree program to see themselves in a posi- 
TABLE 5

TOP SIX WORDS CHOSEN BY ALL RESPONDENTS TO DESCRIBE MALE LIBRARIANS $(n=231)$

\begin{tabular}{llcc}
\hline \hline Rank & Descriptor & $\begin{array}{c}\text { No. of } \\
\text { Responses }\end{array}$ & \% Respondents Choosing \\
\hline 1 & Organized & 79 & 34.2 \\
2 & Logical & 55 & 23.8 \\
3 & Friendly & 54 & 23.4 \\
4 & Approachable & 44 & 19.0 \\
5 & Patient & 40 & 17.3 \\
6 & Serious & 37 & 16.0 \\
\hline
\end{tabular}

TABLE 6

PERCENTAGE AND POLARITY OF RESPONDENT-SUPPLIED DESCRIPTORS, PARTITIONED BY SEX AND TYPE OF RESPONDENT

\begin{tabular}{llccccc}
\hline $\begin{array}{l}\text { Type of } \\
\text { Respond. }\end{array}$ & Sex & $\begin{array}{c}\text { No. of } \\
\text { Respond. }\end{array}$ & \% Positive & \% Neutral & \% Negative & $\begin{array}{c}\text { No. of } \\
\text { Descriptors }\end{array}$ \\
\hline Undergraduates & Male & 61 & 31 & 19 & 50 & 32 \\
& Female & 61 & 72 & 14 & 14 & 29 \\
M.L.S. & (All) & 132 & 51 & 16 & 33 & 61 \\
Students & Male & 51 & 60 & 33 & 7 & 15 \\
& Female & 19 & 50 & 25 & 25 & 28 \\
Librarians & (All) & 70 & 53 & 28 & 19 & 43 \\
& Male & 7 & 67 & 33 & 0 & 3 \\
& Female & 22 & 42 & 11 & 42 & 18 \\
& (All) & 29 & 48 & 14 & 38 & 21 \\
\hline
\end{tabular}

tive light; this kind of adaptive defense mechanism was noted by David Sternberg in his study of chiropractic graduate students-a group that also faces a stream of negative and stigmatic messages from the general public. ${ }^{30} \mathrm{~A}$ second, and more serious, problem is a possible demand characteristic of the survey: M.L.S.student respondents knew that the study was being conducted by one of their colleagues and may have been less honest in their responses than they would have been if the questionnaire had originated from outside the university. Because these two explanations are not mutually exclusive, it may be that they both influenced the results in a manner that we cannot assess.

\section{The Twenty Word Pairs}

Table 6 lists the ratings of the twenty word pair responses between the three groups, but excludes those for which no statistical differences were found. For instance, we discovered no differences between any combination of groups in their mean rating of the seven descriptor-pairs: "organized-disorganized," "'antisocialsocial," "patient-impatient," " "pessimistic-optimistic," "logical-emotional," "enthusiastic-blase," or "sensitiveinsensitive." These pairs also tended to score highest and lowest on the rating scales (see averages below).

Elimination of the male M.L.S. students' and male librarians' input into the table causes no statistically significant change in the mean values. Likewise, there is no statistically significant difference in comparisons of the ratings of male librarians' and male M.L.S. students' and those of the rest of the respondentsexcept in male librarians' projections of how others see them. This suggests that the population as a whole sees the male librarian no differently than male librarians see themselves, despite the male librarians' reluctance to believe this assertion.

For the entire sample of respondents, the values (on a 5-point scale) range from a low of 2.13 for organized-disorganized to a high of 3.48 for antisocial-social. The ratings of male librarian respondents differ only slightly from the entire sample: Their 
TABLE 7

TESTS FOR LINEARITY AND SIGNIFICANT DIFFERENCE

\begin{tabular}{lllll}
\hline $\begin{array}{l}\text { One Pole Descriptor } \\
\text { (of Word Pair) }\end{array}$ & Linearity & 3-Groups & 2-Groups & $\begin{array}{c}\text { Difference in Actual vs. } \\
\text { Perceived Image? }\end{array}$ \\
\hline $\begin{array}{l}\text { Organized } \\
\text { Submissive }\end{array}$ & $p<0.03$ & & & No \\
Meek & $p<0.05$ & & & Yes \\
Nervous & $p<0.05$ & & $p<0.05$ & Yes \\
Approachable & & & & Yes \\
Athletic & & & & Yes \\
Effeminate & & & & Yes \\
Reserved & $p<0.02$ & $p<0.01$ & Yes \\
Conservative & $p<0.01$ & $p<0.01$ & $p<0.01$ & Yes \\
Attractive & $p<0.02$ & $p<0.02$ & $p<0.01$ & No \\
Serious & $p<0.01$ & $p<0.02$ & $p<0.01$ & Yes \\
Follower & & & Yes \\
Subdued & & & Yes \\
\hline
\end{tabular}

highest average value (3.69) is for the descriptor-pair leader-follower and their lowest (1.62) for unathletic-athletic.

\section{Male Librarians' and \\ Male M.L.S. Students' \\ Perceived Responses}

The investigators carried out various statistical tests using the responses to the twenty word pairs, as indicated in table 6 . A Spearman correlation of responses among the three groups measured the strength of the relationship between responses to the descriptor-pair scales and type of respondent, i.e., freshman English student, M.L.S student, or university librarian. This measure was based on the notion that M.L.S. students represent a transitional state (in terms of attitude, at least) between undergraduate students and working professionals.

Thus, a strongly positive or negative correlation between the hypothesized order of the groups and the mean responses of each on a particular item would indicate that a perceived attribute grows stronger or weaker as we move from undergraduate student to M.L.S. student to librarian. For example, the average response of the undergraduate students on a 5-point scale ranging from meek to aggressive is furthest from the meek end of the scale compared to the other two groups; the average of the M.L.S. students is next furthest; and the mean response of the librarians closest.

In general, the closer a respondent is to the profession, the more likely he or she is to choose a point on the positive end of the scale for certain attributes. A correlation between degree of membership in the profession and positive perceptions of male librarians hold true for at least three of the twenty descriptor scales used in the study.

In table 6, we report the value of Spearman's rho (rs); an asterisk $\left({ }^{*}\right)$ indicates that the correlation is statistically significant at the 0.05 level, while two asterisks $\left({ }^{* *}\right)$ indicate significance at the 0.01 level. The results suggest that librarians view their male colleagues as meeker, less friendly, and more nervous, yet more liberal, attractive, witty and leaderlike than do nonprofessionals or members of the undergraduate public.

Word pair responses are also compared as separate groups by type of respondent in order to determine if there are any statistically significant differences. Here the $F$-test was used to compare means among these three groups on word pair responses. Then the M.L.S. students' and librarians' responses are combined into a single group and compared to the freshman English students' responses, using the $T$-test, to see if there are any statistically significant differences among the means of those two groups. For each of these tests we report the value of $F$ and $T$, along with single and double asterisks as described above.

We also compare the actual versus perceived $(\mathrm{A} / \mathrm{P})$ responses to see if differences exist between them; in other words, how 
well do the projections of male librarians regarding how other people view them correspond to the actual rankings of the other respondents? We used a T-test to compare the means for the two samples on each question.

In the final column of table 6 , we indicate (again with single and double asterisks) those thirteen descriptor pairs in which the male librarians' perceived image differs significantly from the actual image measured by this survey at the 0.05 and 0.01 levels. Because we apply four different tests to twenty different descriptor pairs under this criterion, it is also likely that some of the pairs are statistically significant (on a given test) because of chance alone.

\section{"The male librarian sees himself in a worse light than the general popula- tion actually pictures him."}

Table 7 shows that there are differences among the groups with regards to the word pairs meek-aggressive, nervouscomposed, conservative-liberal, attractiveunattractive, serious-witty, and leaderfollower. The table also shows that in over half of the word pairs, the way the male librarian is perceived in fact and the way he thinks he is being perceived are significantly different. In each case, his perceived image is more negative than the actual image. This would suggest that the male librarian sees himself in a worse light than the general population actually pictures him.

\section{DISCUSSION}

The other descriptors chosen by the undergraduate students as applicable to the male librarian are, overall, slightly positive. Yet, when controlling for sex of respondent, the women's responses are overwhelmingly positive and the men's responses somewhat negative. These data are supported by other studies in which men have been shown to receive a greater degree of disapproval from men going into female-dominated professions than by women. ${ }^{31,32}$ Studies of perceptions of male nurses have shown that men feel nursing to be inappropriate for men while women do not hold the same bias. ${ }^{33,34}$

The other descriptors chosen by M.L.S. students and librarians as applicable to the male librarian are, overall, positive as well, but somewhat less so than those chosen by the freshman English students. This is more evident among women than men and may be explained by the fact that it is understandable that male librarians and men entering the profession would be less likely to criticize themselves. A reason for the women's more negative responses may be due to their more personal knowledge of male librarians.

Under these circumstances, shortcomings can be seen more clearly by this group than by the freshman English students who perceive male librarians from across a desk. This assertion seems to be supported by the fact that negative responses from freshman English students are often physically oriented, e.g., badly dressed, while M.L.S. students' and librarians' negative responses are more personalityor virtue-oriented, e.g., misfit or selfish. An alternative hypothesis might be that women generally disapprove of men entering their profession.

Among the twenty word pair descriptors, freshman English women selected organized, friendly, and approachable almost equally, while freshman English men listed organized, logical, and composed as their top three choices, with approachable fourth and friendly to be found nowhere. This pattern continues among M.L.S. students and librarians: women consistently rank approachable and friendly, while men do not.

There may be two reasons for the above results. The first is that women may look at librarianship more from a helping or interpersonal communication perspective, and so choose words like friendly and approachable, while men may look at the profession as an information-dispensing process, thus opting for words like logical, organized, and composed. The second reason may be that male librarians are more friendly to female than to male patrons and thus appear more approachable to 
women patrons. To determine which is the case, a future study could examine men's and women's views of male and female librarians. Responses could then be compared to see if a sex bias exists.

M.L.S. students chose intelligent, knowledgeable, and helpful as frequently as freshman English students did. What is interesting is the high ranking of misfitunconventional, which is mentioned by female M.L.S. students, but not by males. It is not mentioned by any freshman English students or librarians. The reason for this is unclear, but one may speculate that women who go into librarianship may see it as a more feminine profession than women in general. After they graduate and begin practicing, they see that men do fit in and change their ideas. This would account for the lack of these responses among female librarians; an alternative hypothesis is that this is simply the response of a small, idiosyncratic sample.

Among the M.L.S. students' responses, the descriptors unathletic and effeminate appear among the top responses; they also appear in the librarians' responses. Why were these among the top five word pair descriptors chosen by the library group and not among those chosen by the freshman English students? We believe that the librarian respondents took the survey topic in a personal way and responded defensively. Aware that the questionnaire dealt with their image and that these two particular descriptors affect their image relatively strongly, they emphasized them in their ratings. This defensive reaction might also explain the occurrence of words like subdued, conservative, and serious ranking relatively high among M.L.S. students but low among freshman English students.

The word pair and other descriptors most frequently chosen by librarians focus on professional qualities, i.e., how male librarians come across on the job. This is demonstrated by the presence of such descriptors as organized, logical, friendly, and intelligent and by such new descriptors as leader, liberal, outspoken, defensive, competent, and selfish, which did not appear in the M.L.S. students' and freshman English students' responses.
The overall descriptor ratings are positive. This has been found to be true in other studies as well. ${ }^{35,36}$ Overall descriptor ratings are even more positive when male M.L.S. students' and male librarians' responses are isolated. This finding supports Fisher's evidence that the occupational and self-concepts of librarians are relatively high. ${ }^{37}$

The undergraduate, M.L.S. student, and librarian groups all saw differences in four of the twenty word pair descriptors. Undergraduate students rate the male librarian as more conservative, less attractive, more serious, and less of a leader than M.L.S. students-and even less so than librarian respondents. This finding agrees with the notion that the undergraduates see only the "reference desk" aspect of the librarian while M.L.S. students and librarians recognize other sides.

When M.L.S. students' and librarians' responses are compared with freshman English students' responses, the results are even more pronounced.

Striking differences result when the male librarians' perceived image of male librarians is compared with the actual image found in the survey results. The perceived image is more submissive, meek, nervous, effeminate, reserved and subdued and less approachable, athletic, attractive, and leaderlike than it is in fact viewed by the sample client group. A significant difference exists in eleven of twenty word pair descriptors.

\section{"Clift's study of public librarians and their patrons shows that patrons' perceptions tend to be closer to mea- sured personality profiles of librari- ans than the perceptions of the librar- ians themselves."}

The fact that librarians believe that they are viewed in a more negative light than others see them has been previously demonstrated. ${ }^{38,39}$ For example, Clift's study of public librarians and their patrons shows that patrons' perceptions tend to be closer to measured personality profiles of librarians than the perceptions of the librarians 
themselves. Thus, while male M.L.S. students and male librarians in our sample believe that public views of them are relatively negative, this unflattering portrait is not supported by the survey responses. At the same time, real differences may exist between men choosing librarianship as a profession and the general population of males. Studies of perceived differences do not allow conclusions to be drawn about actual differences.

The frequency with which women and men respondents chose certain descriptors to portray male librarians shows that they view the male librarian differently. Furthermore, the members of the male library group feel the male librarian is looked upon negatively when he is, in fact, looked upon positively. It is not known why this difference in perception exists. Further study on how men and women perceive librarianship in general and on what they believe the role of the librarian is or should be needs to be done. In addition, more research should be undertaken on why male librarians believe that other people view them negatively, and how male librarians can change their attitude about their image. In methodological terms, further studies should sample larger numbers of practicing li- brarians, particularly male librarians; more representative samples of university client populations; and use methods that reduce the demand characteristics involved in asking M.L.S. students to pass judgment on their own choice of profession.

\section{CONCLUSION}

In contrast to the perceptions of male M.L.S. students and librarians, the public's image of the male librarian appears to be quite positive and unlike the popular stereotype that is sometimes portrayed in the media. Yet male librarians still see themselves as having a negative image among their clients. They are fighting an image that does not exist, at least not among the university public.

Librarians today seem more and more preoccupied with improving their image. This is wasted effort. As librarians, we need to learn to laugh at the "out of touch with reality" image that the media sometimes portray. As Karen Hyman aptly suggests, "We need to stop doing battle in last year's war, to stop worrying about what they think we look like and get out the message of what we do-the wide variety of skills we possess and the services we can provide. ${ }^{, 40}$

\section{REFERENCES}

1. Liz Chapman, "Popular Images," New Library World 81:153-54 (Aug. 1980).

2. Rosemary Magrill, Occupational Image and the Choice of Librarianship as a Career (Ph.D. diss., Univ. of Illinois, 1969).

3. Neal L. Edgar, "The Image of Librarianship in the Media," in Sidney L. Jackson and others, A Century of Service: Librarianship in the United States and Canada (Chicago: American Library Assn., 1976), p.303-20.

4. Laura Gottschalk, "A Cause for Concern-TV Stereotypes." School Library Journal 23:39 (Nov. 1976).

5. Margot McKinney, "The Nabisco Chipster Image-and Worse!" Wilson Library Bulletin 47:457-63 (Jan. 1973).

6. Jeanne Osborn, "The Ghost of the Hairy Javelin," American Libraries 2:747-49 (July-Aug. 1971).

7. "Image: How They're Seeing Us," American Libraries 16:281 (Mar. 1985); 16:145 (May 1985); 16:372 (June 1985); 16:463 (July/Aug. 1985).

8. Arnold P. Sable, "The Sexuality of the Library Profession: The Male and Female Librarian," Wilson Library Bulletin 43:748-51 (Apr. 1969), p.748.

9. Allan Angoff, "The Male Librarian-an Anomaly?" Library Journal 84:553-56 (Feb. 1, 1959), p.553.

10. Liz Robinson, "Vital Statistics," SLA News 179:19-20 (Jan.-Feb. 1984).

11. Angoff, p.553.

12. Wayne H. Decker, "Occupation and Impressions: Stereotypes of Males and Females in Three Professions," Social Behavior and Personality 14:69-75 (Jan. 1986). 
13. Jody Newmyer, "The Image Problem of the Librarian: Femininity and Social Control," Journal of Library History 11:44-67 (Jan. 1976).

14. Howard Clayton, "Femininity and Job Satisfaction among Male Library Students at One Midwestern University," College \& Research Libraries 31:388-98 (Nov. 1970).

15. Joseph S. Winters, The Inventoried Interests of Male Librarians (Ph.D. diss., New York Univ., 1962).

16. Susan Hesselbart, "Women Doctors Win and Male Nurses Lose," Sociology of Work and Occupations 4:49-62 (Feb. 1977).

17. Sable, p.749.

18. J. Hart Walters, Jr., Image and Status of the Library and Information Services Field (Washington, D.C.: Office of Education, Bureau of Research, DHEW, 1970). ED 045130.

19. Pauline Wilson, Stereotype and Status (Westport, Conn.: Greenwood, 1982).

20. Martha Merrill, "Truth in Advertising-Not for Librarians!" Southeastern Librarian 34:17-18 (Spring 1984), p.17.

21. Paul E. Panek, Michael Rush, and James Greenawalt, "Current Sex Stereotypes of 25 Occupations," Psychological Reports 40:212-14 (Feb. 1977).

22. Eva H. Shinar, "Sexual Stereotypes of Occupations," Journal of Vocational Behavior 7:99-111 (Aug. 1975).

23. Robert B. Clift, The Personality and Occupational Stereotype of Public Librarians (Ph.D. diss., Univ. of Minnesota, 1976).

24. Neal L. Edgar, "The Image of Librarianship in the Media," In Sidney L. Jackson and others, A Century of service: Librarianship in the United States and Canada (Chicago: American Library Assn., 1976), p.303-20.

25. Eugenia Mauldin, "Our Image is Showing," Tennessee Librarian 24:127-28 (Summer 1972).

26. Charles Osgood, George Suci, and Percy Tannenbaum, The Measurement of Meaning (Urbana: Univ. of Illinois Pr., 1957).

27. Edwin Inglee Megargee, The California Psychological Inventory Handbook (San Francisco: JosseyBass, 1972).

28. Harrison G. Gough, "The Adjective Check List as a Personality Assessment Research Techniques," Psychological Reports 6:107-22 (Feb. 1960).

29. John Agada. "Studies of the Personality of Librarians," Drexel Library Quarterly 20:24-45 (Spring 1984).

30. David Sternberg, Boys in Plight: A Case Study of Chiropractic Students Confronting a Medically Oriented Society (Unpublished doctoral diss., New York Univ., 1969).

31. Marilyn Haring and others, "Sex-Biased Attitudes of Counselors: the Special Case of Nontraditional Careers," Counseling and Values 27:242-47 (July 1983).

32. Linda Burzotta Nilson, "The Occupational and Sex Related Components of Social Standing," Sociology and Social Research 60:328-36 (Apr. 1976).

33. Edward LaRoche, "Regressional Analysis of Attitudes toward Male Nurses," Journal of Psychology 113:67-71, 74 (Jan. 1983).

34. Louise F. Fitzgerald, "On the Reciprocal Relationship between Gender and Occupation: Rethinking the Assumptions Concerning Masculine Career Development," Journal of Vocational Behavior 27:109-22 (Aug. 1985).

35. Patricia Anderson, "Image vs. Imagination; or Do We Really Know What the Public Is Thinking?" New Jersey Librarian 15:8-10 (Spring 1982).

36. U. Bloch and T. Bloch, "Occupational Perceptions of Librarians by High School Students," Library Quarterly 51:292-300 (July 1981).

37. William H. Fisher, Study of the Occupational and Self-Concepts of Librarians (Ph.D. diss., Univ. of Southern California, 1981).

38. Clift, "Personality and Occupational Stereotype of Public Librarians."

39. Walters, Image and Status.

40. Karen Hyman," Afterword," New Jersey Libraries 15:11 (Spring 1982), p.11. 


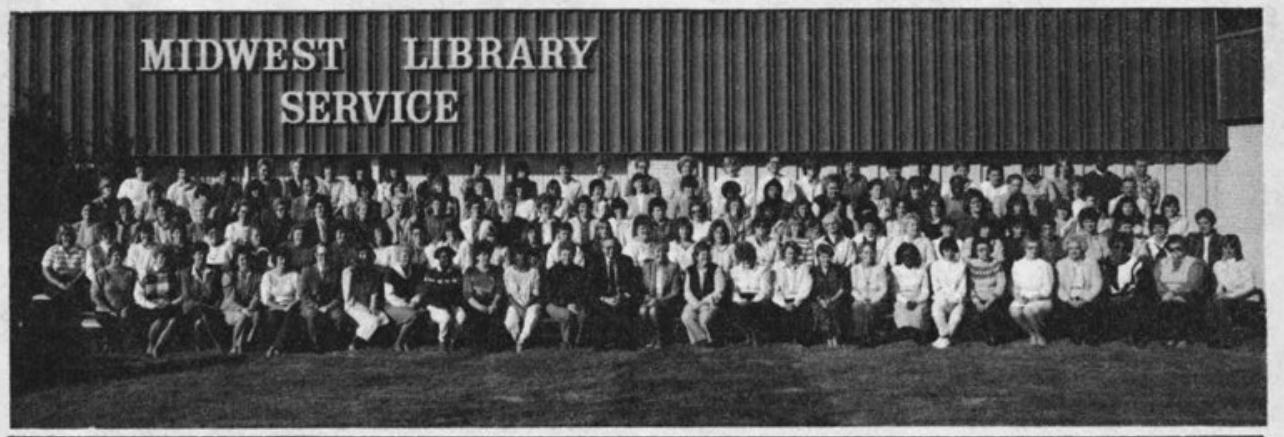

\section{MLS-160 People, 27 Years of Service to Libraries}

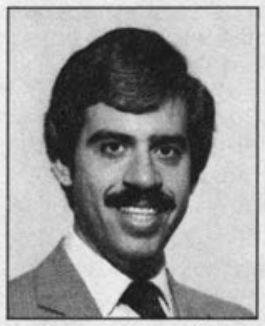

Jay Askuvich

General Sales

Manager

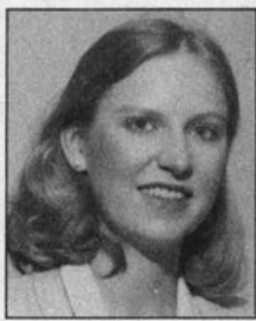

Eva Mahanna Southwest

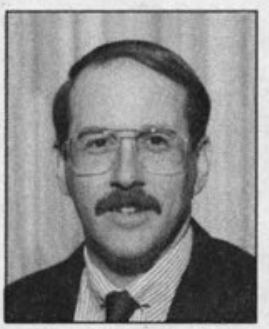

Scott Schmidt

Midwest

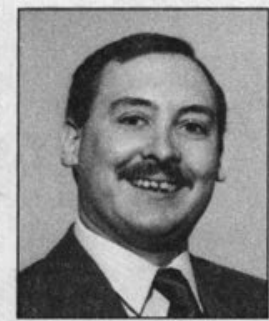

Forrest Link

Northeast

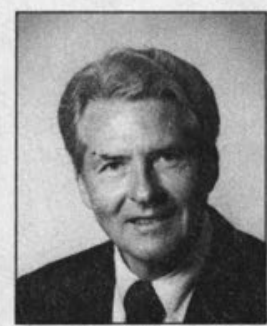

Carl Dorr Southeast

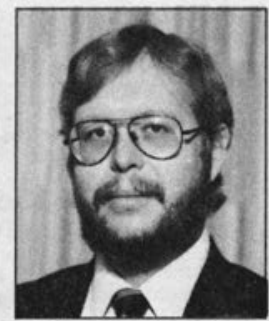

Kim Anderson

Mountain Plains

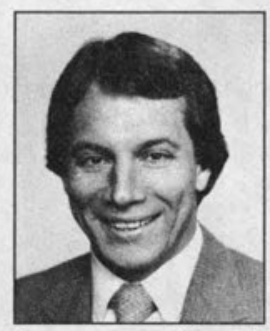

Lawrence Nagel West

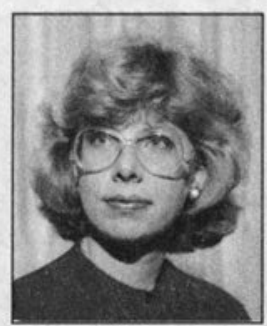

Lorraine Best Canada

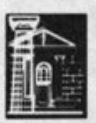

\section{Midwest Library Service}

11443 St. Charles Rock Road Bridgeton, MO 63044, USA

Call toll-free 1-800-325-8833

Missouri librarians call toll-free 1-800-392-5024 Canadian librarians call toll-free 1-800-527-1659 